\title{
ARTIGOS
}

\section{LITERATURA E FORMAÇÃO: NOTAS SOBRE O LUGAR DO LITERÁRIO NAS INSTITUIÇÕES DE ENSINO

\author{
ANDRÉ CECHINEL'
}

\section{RESUMO}

Este ensaio propõe-se a discutir o lugar formativo da literatura num momento em que sua presença institucional se vê precarizada por discursos utilitários característicos da cultura de mercado. Para tanto, o argumento divide-se em dois momentos: primeiro, são discutidos alguns dos abalos teóricos sofridos pela literatura no último século e que fragilizaram os dispositivos que antes justificavam sua presença no âmbito formativo; a seguir, o ensaio indica a necessidade de revisitar as categorias de "obra", "leitor" e "tradição" como modo de estabelecer um funcionamento de fato "formativo" para o espaço institucional da literatura. Se o nosso tempo se caracteriza pela aceleração dos objetos, as noções de "obra", "leitor" e "tradição" podem operar como contrapontos capazes de interromper o fluxo contínuo das coisas, ditando uma outra temporalidade para os estudos literários.

LITERATURA • FORMAÇÃO • LEITOR • INSTITUIÇÕES DE ENSINO

\section{LITERATURE AND EDUCATION: NOTES ON THE ROLE OF LITERATURE IN EDUCATIONAL INSTITUTIONS}

\section{ABSTRACT}

This essay intends to discuss the formative role of literature at a time when its institutional presence is regulated by utilitarian discourses characteristic of a market culture. For this purpose, the argument is divided into two moments. Firstly, it discusses some of the setbacks literature suffered in the last century that weakened the discourses that hitherto justified its presence in educational institutions. Then, the essay indicates the need to revisit the categories of "work," "reader" and "tradition" as a way of establishing a "formative" role for literature. If our time is characterized by the acceleration of objects, the notions of "work,"

I "reader" and "tradition" can operate as counterpoints capable of interrupting the Universidade do Extremo Sul Catarinense - Unesc Criciúma (SC), Brasil andrecechinel@gmail.com continuous flow of things, dictating another temporality for literary studies. 
L'objectif de cet article est de discuter la valeur formatrice de la littérature au moment où sa présence institutionnelle est précarisée par des discours utilitaires, caractéristiques de la culture de marché. Pour ce faire, l'argumentation se décompose en deux temps. Tout d'abord, elle examine quelques problèmes théoriques de la littérature du siècle dernier qui ont fragilisé les dispositifs qui justifiaient auparavant sa présence dans le domaine de l'éducation. Ensuite, le texte souligne la nécessité de revoir les catégories "travail ", "lecteur » et "tradition " afin d'établir un travail réellement "formatif " pour l'espace institutionnel de la littérature. Même si notre époque est caractérisée par l'accélération des objets, les notions de "travail ", de "lecteur » et de " tradition " peuvent fonctionner comme des contrepoints capables d'interrompre le flux continu des choses, dictant une autre temporalité aux études littéraires.

LITTERATURE • FORMATION • LECTEUR • INSTITUTIONS D'ENSEIGNEMENT

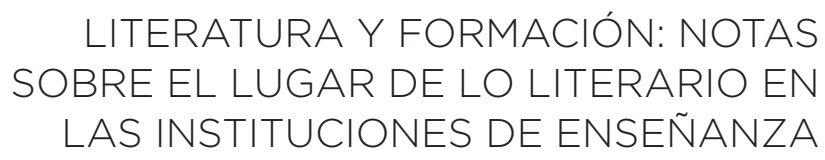

RESUMEN

Este ensayo tiene el propósito de discutir el lugar formativo de la literatura en un momento en que su presencia institucional es precarizada por discursos utilitarios característicos de la cultura de mercado. Para ello, el argumento se divide en dos momentos: en primer lugar, se discuten algunos de los impactos teóricos que sufrió la literatura durante el último siglo, que fragilizaron los dispositivos que antes justificaban su presencia en el ámbito formativo; a continuación, el ensayo indica la necesidad de revisitar las categorías de "obra", "lector" y "tradición" como modo de establecer un funcionamiento efectivamente "formativo" para el espacio institucional de la literatura. Si nuestro tiempo se caracteriza por la aceleración de los objetos, las nociones de "obra", "lector" y "tradición" pueden operar como contrapuntos capaces de interrumpir el flujo continuo de las cosas, dictando otra temporalidad para los estudios literarios. 


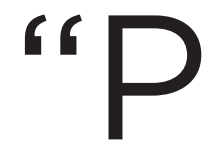

ARA DIZER-TE EM UMA PALAVRA: INSTRUIR-ME A MIM MESMO, TAL COMO SOU, TEM sido obscuramente meu desejo e minha intenção, desde a infância" (GOETHE, 2006, p. 284). O projeto de formação (Bildung) explicitado nas páginas mais famosas do livro de Goethe, Os anos de formação de Wilhelm Meister, jamais poderia ser pensado sem o diálogo com a literatura e as demais artes. Com efeito, ao longo de suas mais de 600 páginas, o célebre Bildungsroman ("romance de formação") faz desfilar diante do leitor uma imensa trupe de artistas apaixonados pela arte, artistas cujas vidas confundem-se com aquelas das várias peças que encenam em seu percurso errante. Em Wilhelm Meister, a formação apresenta-se atrelada a certo abandono de si em meio a uma trajetória incerta que, diferentemente do ideal de vida burguês retratado no romance, não prevê meios e fins específicos garantidores da acomodação do sujeito num mundo de negócios, bens, dinheiro e lucro. Nesse sentido, "autonomia” e "liberdade”, elementos mínimos dessa imagem de formação, significam a abertura ao risco e a uma intransitividade artística sem a qual a razão se instrumentaliza, negando-se a si mesma.

Ora, que a aliança entre formação, arte e intelectualidade não possa ser hoje simplesmente convocada nesses termos é algo há muito anunciado. ${ }^{1}$ No célebre texto de 1915 intitulado "A vida dos estudantes”, Walter Benjamin já apontava a melancolia resultante de um processo formativo estritamente escolarizado e submetido a uma lógica enrijecida de meios e fins e a uma concepção linear de tempo: 
Na medida em que se direciona para a profissão, a universidade desencontra-se forçosamente da criação imediata como forma de comunidade. A estranheza hostil, a incompreensão da escola perante a vida exigida pela arte pode ser realmente interpretada como recusa da criação imediata, não relacionada com o cargo. (BENJAMIN, 2002, p. 40)

A formação, uma vez dissociada das artes e voltada para o mercado de trabalho, afasta o indivíduo do espírito comunitário e degrada a própria ciência. Se a vida do estudante deve pressupor a produção de um atrito mínimo com o mundo estabelecido, o império das profissões converte o estudantado em um corpo passivo à espera de um lugar ao sol, ou melhor, um corpo disposto a adaptar-se justamente às demandas sociais que deveriam ser o objeto de suas críticas. Publicado há mais de 100 anos, o texto de Benjamin está condenado a ver o seu diagnóstico diariamente naturalizado nos mais variados espaços de formação, a ponto de constituir um retrato verdadeiro de uma realidade agora convertida na mais violenta regra. Se o ensaio de 1915 lamentava o abandono das artes em nome de uma formação mais estreita dirigida para a vida profissional, hoje podemos lamentar, então, o abandono da própria ideia de educação e, paralelamente a isso, a mera sobrevivência do artístico-literário como ilhas de intransitividade em meio a uma formação utilitária e pragmática.

A literatura é precisamente uma dessas ilhas que habita o centro desse impasse. Não raro destina-se a ela um papel grandioso no âmbito da educação formal, porém a grandiloquência com que é anunciada sua tarefa contrasta vivamente com as condições concretas para a sua realização. Assim lemos, por exemplo, nas Orientações curriculares para 0 ensino médio - OCEM -, documento de 2006, publicado pelo Ministério da Educação - MEC -, que estabelece as diretrizes gerais para o ensino de literatura no Brasil: "o ensino de Literatura (e das outras artes) visa, sobretudo, ao cumprimento do Inciso III dos objetivos estabelecidos para o ensino médio", que diz respeito ao "aprimoramento do educando como pessoa humana, incluindo a formação ética e o desenvolvimento da autonomia intelectual e do pensamento crítico" (BRASIL, 2006, p. 53). São citadas, a seguir, as conhecidas palavras de Antonio Candido sobre o aspecto "humanizador" do texto literário: "a literatura desenvolve em nós a quota de humanidade na medida em que nos torna mais compreensivos e abertos para a natureza, a sociedade, o semelhante"2 (apud BRASIL, 2006, p. 54). Para além do desconforto que de pronto provoca a tese de um "aprimoramento" do educando como pessoa "humana", as condições objetivas para o ensino de literatura não são nada animadoras, e desnudam, em muitos casos, não a emancipação do "sujeito humano”, mas sim a sua captura quase que integral à dinâmica mais Antonio Vários escritos. 5. ed. Rio de Janeiro: Ouro sobre Azul, 2011. 
agressiva daquele mesmo mundo das mercadorias de que ele haveria de se libertar se bem formado: ali onde a literatura, por ser "difícil”, não é substituída por formas mais simplificadas, ela então se vê submetida ao mundo dos vestibulares e avaliações, cujo intento, cabe insistir, não é a promoção da liberdade e da autonomia dos sujeitos, mas sim a divisão e distribuição dos espaços que cada um pode pleitear na vida social produtiva. Neste último caso, em particular, o contato com o literário se inscreve numa lógica de competição mais ampla que domestica a potência supostamente disruptiva atribuída à literatura nos documentos oficiais. Encarar esse quadro embaraçoso constitui, antes de mais nada, um gesto de coragem e honestidade.

O presente ensaio propõe-se a discutir justamente o cenário de profunda precariedade que regula o lugar dos estudos literários hoje nas instituições de ensino. Para tanto, o texto divide-se em dois momentos fundamentais: primeiramente, busca rememorar de modo sucinto alguns dos abalos teóricos sofridos pela literatura ao longo do século XX e que demandam uma reconfiguração discursiva capaz de justificar o porquê de sua presença institucional. Refiro-me aqui, entre outros, à crise do discurso de nação, à insuficiência do conceito de literariedade, ao império da ideia de texto e gêneros textuais e, por consequência, à crise do objeto nos estudos literários. A seguir, atravessado esse "balanço" inicial, o ensaio debate brevemente a necessidade de uma conceituação forte para as noções de "obra”, "leitor" e "tradição", operadores mínimos que implícita ou explicitamente conduzem o ensino de literatura e que se apresentam, uma vez mais, como desafios teóricos urgentes para a teoria literária. Longe desses desafios, os objetos e a própria área aqui em pauta tendem a entrar em sintonia com o fluxo espetacular de estímulos e imagens do tempo presente e, dessa forma, a se traduzir em práticas distantes da tão propalada “formação humana”.

\section{DA DIFICULDADE DE DIZER “LITERATURA”}

É sob a sombra do discurso de nação ou a partir de seus destroços que se dá muito do que ainda hoje ocorre no domínio do ensino de literatura. Como se sabe, "no século XIX, quando ela [a literatura] se tornou disciplina autônoma (sob a forma de história literária), seu estudo servia como cimento das nacionalidades" (PERRONE-MOISÉS, 2016, p. 76). Decorre desse instinto de nação do século XIX, portanto, a forma como os currículos organizam o estudo do literário a partir das literaturas nacionais, distribuindo os "conteúdos", autores e obras ao longo de uma faixa temporal que segue linearmente desde o "surgimento" de determinada tradição local até o balanço contemporâneo de sua situação. A noção de tempo subjacente a esse encarceramento classificatório, aliás, encontra-se em profunda sintonia com o próprio espírito positivista do 
século XIX, um tempo que segue cumulativa e progressivamente até culminar no momento presente. Seja por meio dos períodos literários ou estilos de época, seja por meio da conhecida grade curricular que tece cortes geográfico-temporais relativamente estáveis e harmônicos nessa mesma sequência histórica e estética, o fator de organização é no fim o mesmo, a expressão do caráter tipicamente nacional de certas obras e o papel decisivo por elas desempenhado na consolidação das conquistas literárias de um dado povo. É como tal, em sua aliança com a história da literatura e sob a égide de impulsos nacionalistas, que os estudos literários se firmam como disciplina.

São inúmeras as críticas tecidas a esse modelo orientador que, no entanto, sobrevive institucionalmente sob um funcionamento autômato. Em primeiro lugar, realizar a leitura dos textos literários a partir de escolas e estilos de época via de regra é obedecer a uma agenda conceitual prévia e enrijecida que impede o imprevisto de surgir no contato efetivo com os artefatos artísticos. Em outras palavras, lê-se José de Alencar como um escritor romântico, Machado de Assis como um escritor realista, quando sabemos perfeitamente que, em muitos casos, o que há de mais potente num autor é aquilo que ele escreve contra o seu tempo, confundindo a própria temporalidade que busca controlar sua produção. Nesse esquema, a leitura da obra na sua integralidade pode ser inclusive substituída por excertos capazes de ilustrar a acomodação de um autor num determinado período e em suas respectivas características dominantes. É por isso que as OCEM alertam: "não se deve sobrecarregar o aluno com informações sobre épocas, estilos, características de escolas literárias, etc., como até hoje tem ocorrido” (BRASIL, 2006, p. 54). O alerta, contudo, não se transfere de pronto para o âmbito da prática, como provam os diferentes livros didáticos que enclausuram as obras nesse cenário de listas e classificações.

Em segundo lugar, com as experiências totalitárias do século XX, a crise do modelo iluminista e centralizador de Estado-Nação, as críticas voltadas à noção de "origem" nas ciências humanas, o descentramento do sujeito cartesiano, a "morte" do autor como figura reguladora da crítica literária, a globalização, o fluxo de mercadorias e a suposta porosidade das fronteiras nacionais, o bombardeio de denúncias dirigidas à parcialidade do cânone, entre outros, com tudo isso, torna-se muito difícil insistir ainda hoje na validade da defesa do nacional ou nas versões teleológicas da história da literatura como princípios legítimos para a organização curricular do ensino de literatura. Seja qual for o motivo, o fato é que um dos mecanismos mais comumente acionados para conferir coesão e um fio condutor ao tratamento do literário viu sua estrutura interna desmoronar, restando apenas os destroços ou restos que, contudo, na falta de um outro princípio articulador mais forte, estamos condenados a revisitar mecanicamente. Enfim, o discurso de nação e a 
história da literatura, além de por vezes contornarem ou prescindirem do contato direto com as obras, projetam as sombras de uma falsa e perigosa totalidade.

Ora, uma alternativa a esses modelos extrínsecos de entrada no literário seria a possibilidade de atuar a partir de elementos balizadores do que é propriamente constitutivo da literatura, os artifícios ou componentes de sua maquinaria interna que a singularizariam em relação ao demais gêneros textuais ou à linguagem cotidiana. $\mathrm{O}$ "formalismo russo", como sabemos, foi precisamente uma tentativa de afastar a literatura da "fala prosaica”, ou melhor, de enfrentar a "má compreensão da diferença que opõe as leis da linguagem cotidiana às da linguagem poética" (CHKLÓVSKI, 2013, p. 89). A chamada "literariedade", isto é, o traço definidor do literário como literário, estaria posta, pois, no processo de "desautomatização" do uso da linguagem e de singularização dos objetos, procedimento que "consiste em obscurecer a forma, em aumentar a dificuldade e a duração da percepção” (CHKLÓVSKI, 2013, p. 91). Em outras palavras, literatura é “estranhamento" (ostranenie), um modo organizado de agredir o caminho automatizante que a vida cotidiana impõe à nossa relação com as formas linguísticas. Se, por um lado, a nossa tendência no dia a dia é lidar com os objetos de maneira habitual, inconsciente ou mesmo acelerada, a forma literária é aquela que nos faz frear e olhar para as coisas como se fosse pela primeira vez: “a arte é um meio de experimentar o vir a ser do objeto, o que já 'veio a ser' não importa para a arte” (CHKLÓVSKI, 2013, p. 89).

A arte como um procedimento, nesse sentido, recorre a ferramentas próprias dela e das quais deve se ocupar o crítico literário para apreender o seu funcionamento. A sucessão de períodos literários é substituída agora por uma "gramática” específica da literatura e por formas - versos, sons, ritmos, imagens, rimas, esquemas métricos, tipos narrativos, etc. - que surgem, deformam ou "desautomatizam” a fala cotidiana, convertem-se elas também paulatinamente em funções dominantes e solicitam, por sua vez, desvios posteriores. Nas palavras de Jakobson (2002, p. 517), “desvios contínuos no sistema de valores artísticos levam a desvios contínuos na avaliação de diferentes fenômenos artísticos”, ou seja, formas antes tomadas como imperfeitas, diletantes ou simplesmente equivocadas podem ressurgir num outro momento, sob um novo registro, como capazes de alterar ou transformar as funções então dominantes e de, nesse caso, demandar avaliações críticas antes imprevistas. Em resumo, portanto, a literatura opera historicamente por meio de um processo dialético de diálogo com a tradição e crítica dela: “manter a tradição e fugir dela compõem a essência de todo novo 
trabalho artístico" (JAKOBSON, 2002, p. 518). Logicamente, ao contrário da simples sucessão de períodos literários organizados desde princípios históricos e estéticos "externos" às obras, o formalismo russo insiste na internalidade de sua base analítica, partindo de um corpo teórico capaz de permitir o enfrentamento com o "fato literário" em sua suposta imanência.

A renúncia à tese de literariedade nos estudos literários parece hoje um dado autoevidente, conforme atesta o próprio tom casual com que as OCEM descartam o assunto em apenas três linhas do documento:

Houve diversas tentativas de estabelecimento das marcas da lite-
rariedade de um texto, principalmente pelos formalistas e depois
pelos estruturalistas, mas essas não lograram muito sucesso, dada
a diversidade de discursos envolvidos no texto literário. (BRASIL,
2006, p. 55)

Curiosamente, entretanto, algumas linhas depois, o documento vai recorrer justamente ao "estranhamento", possivelmente a partir de um uso pré-conceitual do termo, para estabelecer o traço definidor da experiência estética:

\footnotetext{
Qualquer texto escrito, seja ele popular ou erudito [...], deve passar pelo mesmo crivo que se utiliza para os escritos canônicos: Há ou não intencionalidade artística? [...] Proporciona ele o estranhamento, o prazer estético?. (BRASIL, 2006, p. 55)
}

Como no caso do periodismo e da defesa da tradição nacional, as noções formalistas, embora descartadas ou consideradas insuficientes em suas implicações conceituais, sobrevivem nos manuais de literatura destituídas do substrato que as adensaria num uso verdadeiramente crítico. Afinal de contas, o que significa "proporcionar estranhamento" no contexto do documento? A tentativa de responder à pergunta nos faria retornar aos impasses que as OCEM não enfrentam até as últimas consequências e que pediriam uma teorização mais contundente.

Em linhas gerais, as várias críticas lançadas contra o "formalismo russo" e a ideia de literariedade podem ser aqui resumidas, para fins didáticos, em dois pontos fundamentais. Em primeiro lugar, as premissas formalistas em torno da arte como "estranhamento" da realidade parecem funcionar melhor quando coladas aos movimentos de vanguarda ou ao gênero poético, em particular, do que quando dirigidas a formas narrativas como o conto e o romance. Aliás, essa é a crítica que Terry Eagleton tece aos formalistas russos, na conhecida obra Teoria da literatura: uma introdução: "pensar na literatura como os formalistas o fazem é, na realidade, considerar toda a literatura como poesia” (2006, p. 9). Nesse 
sentido, a sensação de estranhamento ou de desvio da norma resultaria muito mais de uma maneira de se relacionar com os objetos do que exatamente de artifícios literários que os fariam produzir diferença em relação aos usos comuns ou cotidianos da linguagem. Em outras palavras, a literatura depende de dispositivos exteriores à dimensão da forma para ser tomada como tal - o que sugere, em suma, que o critério da internalidade não apenas não se sustenta por si só, como parece insinuar-se de modo mais convincente quando sob a forma do verso, cuja associação histórica com a imagem da literatura ocorre de imediato. A perspectiva da recepção ou do leitor, deixada de lado pelos formalistas em seus estudos, aqui surge em cena.

Em segundo lugar, como no caso de outras experiências formalistas posteriores, que se concentraram antes nos aspectos linguísticos do que na dimensão mais imediatamente temático-política da experiência literária, o formalismo russo produziu uma "gramática" imanente para a crítica que, se, num primeiro momento, abriu novos caminhos e afastou as análises extrínsecas silenciadoras das especificidades dos objetos com que se deparavam, num segundo momento, passou a apresentar sinais de esgotamento, girando em falso em torno da forma literária e fechando-se para o conjunto vivo de problemas que essa mesma forma evoca a todo momento. Essa crítica aos excessos "instrumentalizadores" de certas teorizações formalistas encontra-se formulada mais recentemente no livro A literatura em perigo, de Tzvetan Todorov:

\section{[...] não apenas estudamos mal o sentido de um texto se nos ate- mos a uma abordagem interna estrita [...]. É preciso também que nos questionemos sobre a finalidade última das obras que julga- mos dignas de serem estudadas. (TODOROV, 2009, p. 32)}

Atentos somente a aspectos formais, reduzimos a literatura "ao absurdo”, isto é, a um conjunto artificial de técnicas e procedimentos que perdem inteiramente a razão de ser se dissociados do ser humano e do mundo por eles invocados ou fabricados.

Eis a nova tarefa da crítica literária, libertar o leitor das amarras de um formalismo que, a essa altura, passa a estar ele também vinculado ao autoritarismo do sentido único. O novo "império do leitor" e a abertura a uma "interpretação plural" poderiam ser aqui lidos, a título de

exemplo, a partir de dois célebres ensaios de Roland Barthes, "A morte do autor" e "Da obra ao texto". ${ }^{3}$ O primeiro, datado sintomaticamente de 1968, anuncia já em suas linhas iniciais a distância mantida em relação ao fechamento do sentido resultante da materialidade imediata da obra 
ou mesmo do seu lugar de origem: "a escritura é a destruição de toda voz, de toda origem. A escritura é esse neutro [...] em que vem se perder toda identidade, a começar pela do corpo que escreve" (BARTHES, 2004, p. 57). A literatura caracteriza-se fundamentalmente não pelos procedimentos formais que a organizam em sua singularidade ou pela relação de tensão que mantém com o real, mas pela radicalidade de uma condição intransitiva capaz de fazê-la desligar-se de qualquer uso específico. Embora o ensaio refira-se ao império da figura autoral como exemplo maior do significado único, esse Autor-Deus alude, na realidade, não apenas a uma figura biográfica de "carne e osso", mas sim a qualquer obstáculo que impeça o leitor de exercer livremente a sua tarefa:

[...] o leitor é o espaço onde se inscrevem, sem que nenhuma se
perca, todas as citações de que é feita uma escritura; a unidade do
texto não está em sua origem, mas no seu destino, mas esse desti-
no já não pode ser pessoal: o leitor é um homem sem história, sem
biografia, sem psicologia. (BARTHES, 2004, p. 64)

Em resumo, a linguagem (literária) e os sentidos que ela libera no contato com o leitor são abertos, plurais, livres, infinitos, desierarquizados e produzidos sob o signo do prazer que impulsiona a atividade de um receptor "sem história, sem biografia, sem psicologia”, ou seja, de um receptor ele próprio livre de demandas teleológicas.

É claro, para emancipar verdadeiramente o leitor, faz-se necessário desobstruir o fluxo de sua atividade de qualquer materialidade imediata que se apresente como obstáculo, e isso significa, em última instância, dissolver a concretude ou totalidade inscrita na própria ideia de obra. É exatamente isso que Barthes empreende no ensaio de 1975 intitulado, não por acaso, "Da obra ao texto":

Diante da obra - noção tradicional, concebida durante muito
tempo, e ainda hoje, de maneira por assim dizer newtoniana -,
produz-se a exigência de um objeto novo, obtido por deslizamen-
to ou inversão das categorias anteriores. Esse objeto é o Texto.
(BARTHES, 2004, p. 66)

Ao contrário da obra, cujo autocentramento encerra um problema imediato para o livre exercício interpretativo do leitor, o texto caracteriza-se pelo fluxo, pelo deslizamento contínuo e por um conceito de interdisciplinaridade que varre do mapa qualquer resquício de origem ou fim específicos que estabeleçam limites definitivos para o horizonte da recepção. Se a obra, de um lado, associa-se a termos como "estrutura”, “centro", “monismo", "fechamento", "significado”, "simbolismo", “consumo”, "metáfora”, etc., o texto, de outro, vincula-se a categorias 
como "pluralidade”, “paradoxo”, “descentramento”, “jogo”, “significante”, “travessia”, “abertura”, "gozo”, “metonímia”, entre outros. É essa a estrutura binária (cf. DURÃO, 2011a) que dita a celebração da multiplicidade interpretativa defendida por Barthes no ensaio-manifesto em pauta. Em seu procedimento desierarquizante, o texto infinito vislumbrado pelo ensaísta termina por desierarquizar, enfim, os traços que deveriam singularizar a literatura entre os demais usos da linguagem: "o Texto participa a seu modo de uma utopia social; [...] ele é o espaço em que nenhuma linguagem leva vantagem sobre outra” (BARTHES, 2004, p. 75).

Ora, para o lugar institucional ocupado pela literatura, os perigos que rondam esse uso genérico do conceito de texto começam justamente aí, na profunda equivalência estabelecida entre todos os tipos de linguagem. No volume dos Parâmetros curriculares nacionais - PCN - que se intitula sintomaticamente Linguagens, códigos e suas tecnologias - observe-se que não há referência alguma à literatura no título -, o "gênero literário" não só é visto como apenas um entre os vários "gêneros do discurso", como a literatura apresenta-se destituída de qualquer traço básico dela definidor, o que conduz a considerações, por assim dizer, embaraçosas ao longo do documento: “O conceito de texto literário é discutível. Machado de Assis é literatura, Paulo Coelho não. Por quê? As explicações não fazem sentido para o aluno" (BRASIL, 2000, p. 16). Segundo esse cálculo, a dificuldade de definir o que é literatura deve nos levar à improvável conclusão de que todos os textos são potencialmente literários e em certa medida se equivalem. O fiel da balança aqui é o leitor:

Quando deixamos o aluno falar, a surpresa é grande, as respostas quase sempre surpreendentes. Assim pode ser caracterizado, em geral, o ensino de Língua Portuguesa no Ensino Médio: aula de expressão em que os alunos não podem se expressar. (BRASIL, 2000, p. 16)

A potência da literatura não está no desafio que lança aos alunos por meio de sua construção específica e complexa de sentidos, mas sim no convite que lhes faz para que se "expressem". Evidentemente, se o objetivo é a "expressão", é certo que os alunos podem se "expressar" a partir da literatura, mas também por meio de qualquer outro "texto".

Seja como for, ainda que as OCEM tenham posteriormente corrigido a vagueza com que os PCN encerram essas questões, os riscos que a noção de texto reserva para o lugar institucional da literatura são inúmeros. Conforme Fabio A. Durão comenta, o conceito de texto é incapaz de gerar objetos, ou seja, ele não permite a valoração de diferentes artefatos, o que também "aponta para o problema de se lidar com o conceito de verdade na prática textual” (DURÃO, 2011a, p. 71). 
O deslizamento contínuo de uma escritura à outra e o fato de que o texto "não deve ser entendido como um objeto computável" (BARTHES, 2004, p. 67) impede o estabelecimento de um limite que possibilite a diferenciação dos objetos; nesse caso, como algo que não pode ser interrompido em seu deslocamento, pode-se dizer que "a realização mais plena do Texto é a de um fluxo linguístico/semiótico” (DURÃO, 2011a, p. 75), um fluxo que, como tal, não se diferencia de outras textualidades nem se apresenta para o escrutínio. Emblema de uma abundância linguística, o conceito perde força política e literária e acaba por se aproximar “da superprodução que caracteriza o capitalismo atual” (DURÃO, 2011a, p. 75). A liberdade do leitor converte-se, ao fim da jornada, em liberdade para o consumo de pedaços descartáveis.

O vasto alcance do conceito de texto e o subsequente abandono parcial da ideia de literatura como um conjunto relativamente estável de obras que partilham de traços comuns e dialogam com determinada tradição histórica converteram a área dos estudos literários num campo ao mesmo tempo profundamente amplo e aberto, porém sem fronteiras mínimas visíveis e, dessa forma, destituído de um objeto imediato. O desfecho melancólico da seção "Conhecimentos de Língua Portuguesa" dos PCN é por si só suficientemente elucidativo desse cenário: “Ao ler este texto, muitos educadores poderão perguntar onde está a literatura [...]. Os conteúdos tradicionais foram incorporados por uma perspectiva maior, que é a linguagem [...]” (BRASIL, 2000, p. 23). Conforme Leyla Perrone-Moisés (2000, p. 347) assinala, “a única maneira de aderir a essa nova situação é abandonar de vez tudo o que justificava o ensino anterior da literatura, desde o mais elementar”. Cabe aqui ressaltar que esse abandono não é precisamente uma impossibilidade: para além do evidente fato de que a literatura vem sendo gradativamente excluída dos currículos escolares, a própria teoria literária já não parece muito convencida de que possui de fato um objeto e, assim, de "teoria literária" passa a se chamar simplesmente Teoria, com "T" maiúsculo. ${ }^{4}$ Nas palavras de Durão (2016, p. 14):

\section{A Teoria (com "T" maiúsculo) representa o resultado de um pro- cesso de autonomização, de separação vis-à-vis a teoria literária, que, como o próprio nome atesta, ainda guardava alguma espécie de vínculo necessário, por mais tênue que fosse, com a literatura.}

Com efeito, um dos sintomas característicos dessa renúncia ao literário decorre da redução das obras a aspectos estritamente temáticos que poderiam ser perfeitamente encarados a partir de outros artefatos 
quaisquer. A Norton anthology of theory and criticism (2001) mantém, desde o título, uma relação problemática com a literatura. Suas mais de 2500 páginas debruçam-se sobre um objeto que vai gradativamente evaporando ao longo das seções, até ser tomado em sua dimensão estritamente temática. Outros manuais não menos famosos, como Literary theory: an anthology (2004), da Blackwell, e Literary theory and criticism (2006), da Oxford, são igualmente claros ao indicar a acomodação da literatura no âmbito temático: embora preservem o "literário" no título, os volumes mostram-se em sintonia com as atualizações mais recentes da Teoria, listando vários ensaios que passam à margem da literatura, embora ofereçam questões políticas que estão na ordem do dia.

De todo modo, vale lembrar: desdobramentos recentes da Teoria (literária), tais como a "ecocrítica” [Ecocriticism], os "estudos da deficiência” [Disability Studies], os "estudos urbanos” [Urban Studies], os "estudos animais" [Animal Studies], os "estudos transnacionais" [Transnational Studies], os "estudos pós-humanos" [Posthuman Studies], os "estudos do meio-ambiente" [Environmental Studies], os "estudos oceânicos" [Oceanic Studies], etc., além de estabelecer uma dinâmica de dependência intelectual em relação à “Teoria de ponta” produzida, via de regra, nos Estados Unidos, reduzem o fenômeno literário a um campo textual em que se testam ou a que se aplicam as demandas teóricas mais recentes. O que testemunhamos nessas operações é a lógica do consumo e uma mecânica de produção semelhante àquela que conhecemos no mercado internacional: os textos literários trabalham como matéria prima (cf. DURÃO, 2015) submetida ao funcionamento de uma complexa maquinaria importada, num esquema que reproduz sem nenhum tensionamento, no campo teórico, os mesmos laços de dependência que a própria teoria por vezes denuncia. De resto, do ponto de vista da formação intelectual, o quadro em questão também não é muito animador: os ingressantes no mundo das Letras dedicam-se fielmente a um desses Studies - áreas muitas vezes fadadas a um desaparecimento precoce, haja vista as constantes atualizações de seus modelos temáticos ou a flutuação de determinados nomes na bolsa de valores da Teoria - para, como no caso da formação tecnicista ou da educação para o trabalho, encontrar um posto futuro na condição de especialista.

\section{DA NECESSIDADE DE DIZER "LITERATURA"}

Habitando incoerentemente os destroços de argumentos que já não mais lhe oferecem uma estrutura elementar sobre a qual se organizar, o ensino de literatura mantém-se à deriva. Dessa forma, sem um rumo claro ou uma regra forte, a presença do literário tende a se reduzir aos princípios do consumo rápido e descartável que imperam na "sociedade do espetáculo”. Nessas condições, em que a literatura, para não 
desaparecer, mimetiza a expectativa de utilidade a que se veem submetidos os mais diversos conteúdos que habitam as instituições formativas, torna-se um exercício improvável insistir no argumento da "formação humana” a que aludem os documentos oficiais. A “formação humana”, caso queiramos ressignificá-la e defendê-la, tem de resultar de um processo, não de acomodação, mas de tensão contínua com a realidade. Como no exemplo de Wilhelm Meister, "formar-se" significa submeter-se ao risco contínuo do desamparo, do abandono, da improdutividade, da intransitividade, enfim, submeter-se ao risco de um mundo artístico-literário que já não reserva grandes promessas, mas que exige muito.

Diante desse quadro, difícil permanecer no terreno das metodologias para o ensino de literatura. Indispensável, antes de mais nada, é uma teorização capaz de oferecer conceitos consistentes de "obra”, "leitor" e "tradição" que estejam em dissintonia com as exigências do tempo presente e sejam capazes de produzir um tensionamento de fato formativo. Esses conceitos poderiam recomeçar a partir de pressupostos básicos, porém não raro deixados de lado. Para a noção de “obra”, por exemplo, em confronto com a ideia de uma textualidade deslizante, cabe lembrar ou acentuar a singularidade irredutível sob a qual ela se apresenta, ou seja, cabe lembrar que a obra só funciona enquanto tal se vinculada a um determinado modo específico de apresentação, em que o "o quê" do artefato confunde-se simultaneamente com o seu "como", sem que um possa ser acionado sem ativar também o outro. Em outras palavras, afastada de sua construção particular, isto é, de sua singularidade ou especificidade, a literatura tende a migrar para o campo apenas temático ou então para formas mais toleráveis como aquelas citadas anteriormente. Preservados em sua apresentação singular, os artefatos literários resistem ao mero processo de predicação ou aplicação que caracteriza as operações da Teoria. Como afirma Durão (2011a, p. 80), "A obra [...] não pode ser submetida a um modelo, ou ser usada para exemplificar o que quer que seja. Há algo de irredutivelmente antididático em si”. É nesse "antididatismo" da obra que se encontra a possibilidade de formação para o leitor.

Sobre o "leitor", em vez de figura que dita livremente e a partir de si mesmo os sentidos dos textos ou suas relações intertextuais infinitas, faz-se importante, ao contrário, defender a sua desconstrução parcial frente à concretude de uma obra que, quanto mais potente, mais resiste ao seu intuito de silenciá-la por meio da interpretação. No lugar de um diálogo em que, a rigor, nem texto nem leitor conversam, a leitura potente decorre antes de um embate, de uma disputa violenta e irreconciliável, em que o leitor quer calar a obra por meio de uma análise precisa, "definitiva”, e a obra desvia-se de si mesma e termina por invocar o leitor uma vez mais, provando ser mais complexa do que a interpretação sobre ela projetada. A "gestão de si”, assegurada pelo contato 
apriorístico com os textos, é substituída, então, pela “desconstrução de si”, resultado de um gesto de entrega e atenção à singularidade do artefato intimidante que ali se apresenta à leitura. Ora, para ser de fato ameaçadora, para poder eventualmente retirar o leitor do lugar por ele ocupado quando do instante da recepção, a obra não pode originar-se diretamente das demandas desse leitor ou se limitar a satisfazê-las. Nesse sentido, fica parcialmente respondida a questão volta e meia lançada quanto à escolha de materiais a partir dos quais trabalhar com os alunos: cânone ou anticânone, a seleção tem de desafiar o leitor e desarmar seus desejos de consumo iniciais. O critério da facilidade, quando um fim em si mesmo, gera consumidores, não leitores críticos.

Por fim, para evitar o risco de terceirizar a tarefa de tecer um princípio articulador coerente para o diálogo entre as várias obras, seria importante restituir a ideia de "tradição" ao lugar que lhe cabe. Ora, isso certamente não quer dizer fazer o elogio da "grande tradição", da genialidade do cânone, ou recorrer a uma estética fixa e imobilizadora, mas sim pensar o conceito de tradição como um operador narrativo inicial e, dessa forma, para sempre incompleto, porém capaz de conferir tanto um sentido histórico e político para os estudos literários quanto de negar-se a si mesmo interna e externamente. Para dizer de outra maneira, o cânone se desestabiliza internamente, por um lado, quando uma obra do passado, velha conhecida nossa, é submetida a um exercício interpretativo capaz de conferir-lhe mobilidade, e externamente, por outro, quando novas obras, vozes silenciadas do passado e do presente, violentam a suposta completude dessa tradição, abrindo uma ferida em seu seio capaz de fazer com que tudo que era até então familiar vibre novamente de modo a produzir atritos criativos e potentes. Diferentemente da mera negação do cânone, o conceito de "tradição negativa” reconhece que o passado nunca se nos apresenta de forma integral, exigindo, pois, uma postura ativa de revisitação, confronto e convívio com as suas ruínas.

Se a formação tem que ver menos com adequação, instrumentalização, e mais com a produção de algum dissenso mobilizador, e se o fluxo ininterrupto de estímulos caracteriza o paradigma central da "sociedade da sensação", então trabalhar com as noções de "obra”, "leitor” e "tradição" nos termos mínimos acima concebidos significa viabilizar um espaço de interrupção e atenção aos objetos que pode assumir tonalidades de fato formativas nos espaços de ensino. Que os conceitos de "literatura”, “autor", "leitor”, "obra”, "interpretação”, etc. são infinitamente mais complexos do que faz parecer o tratamento que aqui lhes foi brevemente conferido não resta dúvida. Ainda assim, abrir mão desses operadores, no momento, é não apenas abandonar a literatura à própria sorte, mas colocá-la a serviço de um utilitarismo que não sustenta relação alguma com ela. Restabelecer um contato “improdutivo” com 
a literatura é a única forma de restituí-la minimamente ao âmbito da formação e à temporalidade que lhe cabe e que ela solicita.

\section{OBSERVAÇÕES FINAIS}

O estrangulamento gradual da literatura nos espaços formativos é um fenômeno complexo, que em grande parte escapa ao funcionamento interno da disciplina e que, portanto, deve ser teorizado para além dos conceitos que pairam sobre a área. O caso da escola, em particular, é emblemático: de instituição que deveria promover o espírito crítico, a autonomia dos sujeitos, a emancipação por meio da apropriação dos conhecimentos historicamente acumulados, a "humanização" como resultado do convívio com o outro e da abertura à alteridade, etc., a escola passa a ser lida como estabelecimento responsável por assegurar a sobrevivência e inclusão posterior dos alunos no mercado de trabalho e na vida produtiva. Quando deixa de cumprir a tarefa de destinar a cada um a parte que lhe cabe no universo adulto, ela vê sua legitimidade questionada de todos os lados. Conforme Christian Laval (2004, p. xi) resume a questão, “a escola neoliberal designa um certo modelo escolar que considera a educação como um bem essencialmente privado e cujo valor é, antes de tudo, econômico”. Segundo esse modelo privado e competitivo, a escola deve, em primeiro lugar, instrumentalizar os alunos, prepará-los para a entrada no mercado de trabalho, algo que a literatura não só não faz, como por vezes se coloca até mesmo como um obstáculo para esse fim. Em resumo, a literatura solicita um tempo "improdutivo" já indisponível ou não mais viável e, assim, no mundo da utilidade e aplicabilidade, ela é simplesmente "inútil”.

Diante desse cenário instrumentalizante e em busca de uma sobrevida no campo da formação, a literatura por vezes ressurge colada àquelas mesmas forças utilitárias e produtivas que estimulam a natureza mercadológica a que as instituições se veem hoje reduzidas. Em poucas palavras, ao seguir sem um rumo claro e estando, pois, à deriva, a literatura coloca-se como mercadoria à disposição de uma apropriação mais pragmática, abrindo mão da sua capacidade de interromper o fluxo normal dos objetos para se apresentar como espetáculo. Com efeito, talvez a literatura só possa sobreviver, em uma cultura de mercado, a partir de certa "espetacularização de si", ou melhor, oferecendo-se também como produto por meio de promessas redentoras. De todo modo, quando não alienada de si mesma, a literatura tende ao desaparecimento institucional, pois sua "inutilidade" é flagrante e incontornável. A literatura não nos ajuda a achar um emprego nem nos capacita para um trabalho ou profissão; a literatura não nos torna "melhores" nem nos "humaniza”, pelo menos não no sentido pragmático costumeiramente associado a esses termos; por fim, a literatura certamente não nos 
ensina a viver; talvez possamos inclusive dizer o contrário, isto é, que a literatura muitas vezes confunde ou nos faz estranhar o nosso modo de viver, colocando dúvidas ali onde havia convicção, muito embora nem mesmo isso seja um traço dela constitutivo. Em suma, a literatura não se oferece a uma apropriação pedagógica ou didatizante muito clara, e o espectro de sua força formativa só se apresenta, sempre de maneira precária ou inesperada, por meio dessa rebeldia primeira.

Assim, as categorias de "obra”, "leitor" e "tradição", tal como aqui rapidamente tratadas, não intentam conferir uma utilidade específica à literatura ou uma função formativa que a faça sobreviver em meio a outras mercadorias, mas buscam, antes, retirá-la de vez da esfera do uso ou da circulação fluida a que se vê submetida e que facilita a sua instrumentalização, mergulhando ainda mais profundamente na mesma intransitividade ou inutilidade radical que ameaça fazê-la desaparecer. A temporalidade a partir da qual esses conceitos foram aqui concebidos contrasta frontalmente com o tempo produtivo e econômico que controla a passagem das instituições de ensino e da própria literatura para a lógica do mercado. Há nisso tudo, é claro, uma grande contradição, uma conduta como que suicida: pode-se argumentar que esse tratamento conduzirá a um desaparecimento ainda mais precoce e integral da literatura dos espaços de formação, e isso parece ser verdade. Por outro lado, resta lançar a inevitável pergunta: em sua versão espetacularizada, não é verdade que a literatura ali já desapareceu? Seja como for, no presente momento, a literatura ainda é o "inútil” habitando o coração das instituições; cabe lutar por esse espaço, ou seja, cabe lutar para que ela ali surja enquanto tal e que, com isso, constitua sempre a lembrança anacrônica de um significado mais verdadeiro da palavra "formação", até que ela enfim simplesmente desapareça, junto com as demais "inutilidades" fundamentais à nossa existência.

\section{REFERÊNCIAS}

BARTHES, Roland. 0 rumor da língua. Tradução de Mário Laranjeira. 2. ed. São Paulo: Martins Fontes, 2004.

BENJAMIN, Walter. Reflexões sobre a criança, o brinquedo e a educação. Tradução de Marcus Vinicius Mazzari. São Paulo: Duas Cidades; 34, 2002.

BRASIL. Parâmetros curriculares nacionais (ensino médio). Parte II - Linguagens, códigos e suas tecnologias. Brasília: Ministério da Educação, Secretaria de Educação Básica, 2000.

BRASIL. Orientações curriculares para o ensino médio: v. 1. Linguagens, códigos e suas tecnologias. Brasília: Ministério da Educação, Secretaria de Educação Básica, 2006.

CHKLÓVSKI, Victor. A arte como procedimento. In: TODOROV, Tzvetan (Org.). Teoria da literatura: textos dos formalistas russos. São Paulo: Editora da Unesp, 2013. p. 83-108.

DURÃO, Fabio Akcelrud. Sobre a relevância dos estudos literários hoje. Linguasagem, São Carlos, v. 2, p. 1-1, 2008. Disponível em: <http://www.letras.ufscar.br/linguasagem/edicao02/02e_fad. php>. Acesso em: 13 abr. 2017. 
DURÃO, Fabio Akcelrud. Do texto à obra. Alea, Rio de Janeiro, v. 13, n. 1, p. 67-81, jun. 2011a. Disponível em: <http://www.scielo.br/scielo.php?script=sci_arttext\&pid=S1517-106X201100010 0005\&lng=en\&nrm=iso $>$. Acesso em: 15 maio 2017.

DURÃO, Fabio Akcelrud. Teoria (literária) americana: uma introdução crítica. Campinas: Autores Associados, 2011b.

DURÃO, Fabio Akcelrud. Fragmentos reunidos. São Paulo: Nankin, 2015.

DURÃO, Fabio Akcelrud. O que aconteceu com a teoria? In: CECHINEL, André. (Org.). O lugar da teoria literária. Florianópolis: EdUFSC; Criciúma: Ediunesc, 2016. p. 13-27.

EAGLETON, Terry. Teoria da literatura: uma introdução. Tradução de Waltensir Dutra. 6. ed. São Paulo: Martins Fontes, 2006.

GOETHE, Johan Wolfgang von. Os anos de aprendizado de Wilhelm Meister. Tradução de Nicolino Simone Neto. São Paulo: 34, 2006.

JAKOBSON, Roman. O dominante. In: LIMA, Luiz Costa (Org.). Teoria da literatura em suas fontes. 3. ed. Rio de Janeiro: Civilização Brasileira, 2002. v. 1, p. 511-518.

LAVAL, Christian. A escola não é uma empresa: o neo-liberalismo em ataque ao ensino público. Tradução de Maria Luiza M. de Carvalho e Silva. Londrina: Planta, 2004.

PERRONE-MOISÉS, Leyla. Inútil poesia. São Paulo: Companhia das Letras, 2000.

PERRONE-MOISÉS, Leyla. Mutações da literatura no século XXI. São Paulo: Companhia das Letras, 2016.

TODOROV, Tzvetan. A literatura em perigo. Tradução de Caio Meira. 2. ed. Rio de Janeiro: Difel, 2009. 